\title{
NOTES
}

\section{Preparation and Properties of Poly(phenylacetylene) Membranes Containing Perfluoroalkyl Groups}

\author{
Yoshio Hayakawa, Masakazu Nishida, Haruhiko Fukaya, \\ and Hiroshige Muramatsu* \\ Government Industrial Research Institute, Nagoya, Kita-ku, Nagoya 462, Japan \\ * Department of Chemistry, Faculty of Engineering, Gifu University, \\ Gifu 501-11, Japan
}

(Received October 22, 1992)

\begin{abstract}
KEY WORDS Poly(phenylacetylene) / Perfluoroalkyl Group / Membrane / Gas Permeation / Pervaporation /
\end{abstract}

Fluorine-containing polymers have drawn much attention as materials for gas separation membrane. ${ }^{1,2}$ Previously we synthesized several poly(phenylacetylene)s containing trifluoromethyl groups on their benzene rings. ${ }^{3}$ The gas permeability of those polymer films was remarkably enhanced by increasing the number of trifluoromethyl groups per monomer unit, namely fluorine content in the polymers. Flexibility, length and bulkiness of the side chains of the polymers are thought to be important factors in controlling permselectivity and permeability, besides stiffness of the polymer backbones. Therefore evaluation of gas permeability of poly(phenylacetylene)s having perfluoroalkyl side chains with different lengths is of great interest. Such polymer films with high fluorine content are also expected to have preferential permeation for organic liquids in pervaporation of aqueous solutions because of their marked hydrophobicity.

The molecular weights of substituted polyacetylenes afforded by catalysts of group 5 and 6 transition metals have been reported to depend on the steric effects of monomers. ${ }^{4,5}$ Thus phenylacetylene possessing a trifluoromethyl group at the ortho-position yields a high molecular weight polymer, leading to a good film forming ability of the polymer. ${ }^{6}$

In the present study, poly[(2-trifluoromethyl-5-perfluoroalkylphenyl)acetylene]s were synthesized and their properties as separation membranes were evaluated.

\section{EXPERIMENTAL}

\section{Materials}

1,1-Dichloro-2,2-difluoroethylene was prepared as reported in the literature. ${ }^{7}$ Tungsten hexachloride obtained commercially was used without further purification. Tetraphenyltin was recrystallized from carbon tetrachloride. Toluene distilled from calcium hydride was used as a polymerization solvent.

\section{Preparation of Monomers}

1-Perfluoroalkyl-4-trifluoromethylbenzene $(\mathbf{1 a}-\mathbf{1 c})$

In an autoclave was placed a mixture of 1-iodo-4-trifluoromethylbenzene $(14.5 \mathrm{~g}, 53.3$ mmol), 1-iodoheptafluoropropane $(18.9 \mathrm{~g}, 63.9$ $\mathrm{mmol})$, copper powder $(8.50 \mathrm{~g}, 0.132 \mathrm{~mol})$ and $\mathrm{N}, \mathrm{N}$-dimethylformamide $(100 \mathrm{ml})$ under nitrogen atmosphere. ${ }^{8}$ The reaction vessel was heated at $105^{\circ} \mathrm{C}$ for $24 \mathrm{~h}$. After cooling the mixture, it was poured into ether and the precipitate was removed by filtration. The 
filtrate was washed with dil $\mathrm{HCl}$ and then with aq $\mathrm{NaHSO}_{3}$, dried over anhydrous $\mathrm{MgSO}_{4}$, and distilled to give $1 \mathrm{a}(9.58 \mathrm{~g}, 57 \%$ yield).

Compound 1a had bp $140-143^{\circ} \mathrm{C} ;{ }^{19} \mathrm{~F}$ NMR $\left(\mathrm{CDCl}_{3}\right)$ : $-63.8 \mathrm{ppm}(\mathrm{s}, 3 \mathrm{~F}),-80.4(\mathrm{t}$, $3 \mathrm{~F}),-112.7$ (q, 2F), -126.7 (s, 2F); MS (70 eV): $m / z$ (relative intensity) $314(100) \mathrm{M}^{+}$, 295 (136) $[\mathrm{M}-\mathrm{F}]^{+}, 245$ (21) $\left[\mathrm{M}-\mathrm{CF}_{3}\right]^{+}$, 195 (323) $\left[\mathrm{M}-\mathrm{C}_{2} \mathrm{~F}_{5}\right]^{+}$.

Similar procedures afforded $\mathbf{1 b}$ and $\mathbf{1 c}$ in $54 \%$ and $71 \%$ yields, respectively.

Compound 1b had bp $134-135^{\circ} \mathrm{C} ;{ }^{19} \mathrm{~F}$ NMR $\left(\mathrm{CDCl}_{3}\right)$ : $-63.8 \mathrm{ppm}(\mathrm{s}, 3 \mathrm{~F}),-76.0$ $(\mathrm{d}, 6 \mathrm{~F}),-183.0(\mathrm{~m}, 1 \mathrm{~F}) ; \mathrm{MS}(70 \mathrm{eV}): 314$ (100) $\mathrm{M}^{+}, 295$ (81) $[\mathrm{M}-\mathrm{F}]^{+}, 245$ (238) $\left[\mathrm{M}-\mathrm{CF}_{3}\right]^{+}, 195(362)\left[\mathrm{M}-\mathrm{C}_{2} \mathrm{~F}_{5}\right]^{+}$.

Compound 1c had bp $95-97^{\circ} \mathrm{C} / 20 \mathrm{mmHg}$; ${ }^{19} \mathrm{~F} \mathrm{NMR}\left(\mathrm{CDCl}_{3}\right)$ : $-63.8 \mathrm{ppm}(\mathrm{s}, 3 \mathrm{~F}),-81.3$ $(\mathrm{t}, 3 \mathrm{~F}),-111.7(\mathrm{t}, 2 \mathrm{~F}),-122.0-122.2(\mathrm{~m}$, $4 \mathrm{~F}),-123.2(\mathrm{~m}, 2 \mathrm{~F}),-126.6(\mathrm{~m}, 2 \mathrm{~F}) ; \mathrm{MS}$ $(70 \mathrm{eV}): 464(100) \mathrm{M}^{+}, 445$ (400) $[\mathrm{M}-\mathrm{F}]^{+}$, $395(50)\left[\mathrm{M}-\mathrm{CF}_{3}\right]^{+}$.

\section{1-(2,2-Dichloro-1-fluorovinyl)-2-trifluoromethyl-} 5-perfluoroalkylbenzene (2a-2c)

To $1 \mathbf{a}(4.23 \mathrm{~g}, 13.5 \mathrm{mmol})$ was added an ethereal butyllithium solution $(25 \mathrm{ml}, 40 \mathrm{mmol})$ at $0^{\circ} \mathrm{C}$ over $1 \mathrm{~h}$. The solution was stirred for additional $2 \mathrm{~h}$ at room temperature and then 1,1-dichloro-2,2-difluoroethylene $(16 \mathrm{~g}, 120$ mmol) was added at $-78^{\circ} \mathrm{C}$ over $30 \mathrm{~min}$. The mixture was stirred for additional $30 \mathrm{~min}$ at room temperature $\left(c a .20^{\circ} \mathrm{C}\right)$ and poured into dil $\mathrm{HCl}$. The ether layer was washed with aq $\mathrm{NaHCO}_{3}$, dried over anhydrous $\mathrm{MgSO}_{4}$, and distilled to give $2 \mathrm{a}(2.60 \mathrm{~g}, 45 \%$ yield $)$.

Compound 2a had bp $95^{\circ} \mathrm{C} / 13 \mathrm{mmHg} ;{ }^{19} \mathrm{~F}$ NMR $\left(\mathrm{CDCl}_{3}\right):-62.2 \mathrm{ppm}(\mathrm{d}, 3 \mathrm{~F}),-80.4(\mathrm{t}$, $3 \mathrm{~F}),-87.2(\mathrm{q}, 1 \mathrm{~F}),-113.1$ (q, 2F), -126.7 (s, 2F); MS (70 eV): 426, 428, 430 (100) $\mathrm{M}^{+}$, 407, 409, 411 (21) $[\mathrm{M}-\mathrm{F}]^{+}, 357,359,361(8)$ $\left[\mathrm{M}-\mathrm{CF}_{3}\right]^{+}, 307,309,311(293)\left[\mathrm{M}-\mathrm{C}_{2} \mathrm{~F}_{5}\right]^{+}$; IR: $1667 \mathrm{~cm}^{-1}\left(-\mathrm{CF}=\mathrm{CCl}_{2}\right)$.

Similar procedures afforded $\mathbf{2 b}$ and $\mathbf{2 c}$ in $33 \%$ and $36 \%$ yields, respectively.

Compound 2b had bp $81-83^{\circ} \mathrm{C} / 7 \mathrm{mmHg}$;
${ }^{19} \mathrm{~F}$ NMR $\left(\mathrm{CDCl}_{3}\right):-62.3 \mathrm{ppm} \quad(\mathrm{d}, \quad 3 \mathrm{~F})$, $-75.9(\mathrm{~d}, 6 \mathrm{~F}),-87.4(\mathrm{q}, 1 \mathrm{~F}),-182.8(\mathrm{~m}$, 1F); MS (70 eV): 426, 428, 430 (100) $\mathrm{M}^{+}, 407$, 409, $411(25)[\mathrm{M}-\mathrm{F}]^{+}, 357,359,361$ (38) $\left[\mathrm{M}-\mathrm{CF}_{3}\right]^{+}, 307,309,311(88)\left[\mathrm{M}-\mathrm{C}_{2} \mathrm{~F}_{5}\right]^{+}$; IR: $1669 \mathrm{~cm}^{-1}\left(-\mathrm{CF}=\mathrm{CCl}_{2}\right)$.

Compound $2 \mathrm{c}$ had bp $70^{\circ} \mathrm{C} / 0.1 \mathrm{mmHg} ;{ }^{19} \mathrm{~F}$ NMR $\left(\mathrm{CDCl}_{3}\right):-62.2 \mathrm{ppm}(\mathrm{d}, 3 \mathrm{~F}),-81.3(\mathrm{t}$, $3 F),-87.3(\mathrm{q}, 1 \mathrm{~F}),-112.0(\mathrm{t}, 2 \mathrm{~F}),-121.6$ $-122.2(\mathrm{~m}, 4 \mathrm{~F}),-123.2(\mathrm{~m}, 2 \mathrm{~F}),-126.5(\mathrm{~m}$, 2F); MS (70 eV): 576, 578, 580 (100) $\mathrm{M}^{+}$, 557, 559, 561 (19) $[\mathrm{M}-\mathrm{F}]^{+}, 307,309,311$ (248) $\left[\mathrm{M}-\mathrm{C}_{5} \mathrm{~F}_{11}\right]^{+}$; IR: $1670 \mathrm{~cm}^{-1}(-\mathrm{CF}=$ $\left.\mathrm{CCl}_{2}\right)$.

\section{(2-Trifluoromethyl-5-perfluoroalkylphenyl)- acetylene $(\mathbf{3 a}-\mathbf{3 c})$}

To a dry ice-acetone cooled $2 \mathrm{a}(2.54 \mathrm{~g}$, $5.95 \mathrm{mmol})$ in ether $(3 \mathrm{ml})$ was added a hexane solution of butyllithium $(11 \mathrm{ml}, 18 \mathrm{mmol})$ over $30 \mathrm{~min}$.

The solution was acidified with dil $\mathrm{HCl}$. The organic layer was washed with aq $\mathrm{NaHCO}_{3}$, dried over anhydrous $\mathrm{MgSO}_{4}$, and distilled to give $3 \mathrm{a}(1.38 \mathrm{~g}, 69 \%$ yield $)$.

Compound 3a had bp $60-61^{\circ} \mathrm{C} / 10 \mathrm{mmHg}$; ${ }^{1} \mathrm{H} \mathrm{NMR}\left(\mathrm{CDCl}_{3}\right): 7.87-7.60 \mathrm{ppm}(\mathrm{m}, 3 \mathrm{H})$, $3.46(\mathrm{~s}, 1 \mathrm{H}) ;{ }^{19} \mathrm{~F} \mathrm{NMR}\left(\mathrm{CDCl}_{3}\right):-63.4 \mathrm{ppm}$ $(\mathrm{s}, 3 \mathrm{~F}),-80.5(\mathrm{t}, 3 \mathrm{~F}),-113.1 \quad(\mathrm{q}, 2 \mathrm{~F})$, $-126.6(\mathrm{~s}, 2 \mathrm{~F})$; MS (70 eV): $338(100) \mathrm{M}^{+}$, $319(40)[\mathrm{M}-\mathrm{F}]^{+}, 269(10)\left[\mathrm{M}-\mathrm{CF}_{3}\right]^{+}, 219$ (520) $\left[\mathrm{M}-\mathrm{C}_{2} \mathrm{~F}_{5}\right]^{+}$; IR: $2124 \mathrm{~cm}^{-1}(\mathrm{C} \equiv \mathrm{C})$, $3310(\equiv \mathrm{C}-\mathrm{H})$.

Similar procedures afforded $\mathbf{3 b}$ and $\mathbf{3 c}$ in $62 \%$ and $78 \%$ yields, respectively.

Compound $3 \mathrm{~b}$ had bp $38-39^{\circ} \mathrm{C} / 4.5 \mathrm{mmHg}$; ${ }^{1} \mathrm{H} \mathrm{NMR}\left(\mathrm{CDCl}_{3}\right): 7.89-7.64 \mathrm{ppm}(\mathrm{m}, 3 \mathrm{H})$, $3.47(\mathrm{~s}, 1 \mathrm{H}) ;{ }^{19} \mathrm{~F} \mathrm{NMR}\left(\mathrm{CDCl}_{3}\right):-63.4 \mathrm{ppm}$ (s, 3F), $-76.0(\mathrm{~d}, 6 \mathrm{~F}),-183.0(\mathrm{~m}, 1 \mathrm{~F}) ; \mathrm{MS}$ (70 eV): $338(100) \mathrm{M}^{+}, 319(33)[\mathrm{M}-\mathrm{F}]^{+}, 269$ (100) $\left[\mathrm{M}-\mathrm{CF}_{3}\right]^{+}, 219$ (233) $\left[\mathrm{M}-\mathrm{C}_{2} \mathrm{~F}_{5}\right]^{+}$; IR: $2121 \mathrm{~cm}^{-1}(\mathrm{C} \equiv \mathrm{C}), 3315(\equiv \mathrm{C}-\mathrm{H})$.

Compound $3 \mathrm{c}$ had bp $46-48^{\circ} \mathrm{C} / 0.5 \mathrm{mmHg}$; ${ }^{1} \mathrm{H} \mathrm{NMR}\left(\mathrm{CDCl}_{3}\right): 7.87-7.64 \mathrm{ppm}(\mathrm{m}, 3 \mathrm{H})$, $3.45(\mathrm{~s}, 1 \mathrm{H}) ;{ }^{19} \mathrm{~F}$ NMR $\left(\mathrm{CDCl}_{3}\right):-63.5 \mathrm{ppm}$ $(\mathrm{s}, 3 \mathrm{~F}),-81.3(\mathrm{t}, 3 \mathrm{~F}),-111.9(\mathrm{t}, 2 \mathrm{~F})$, 
$-121.8--122.0(\mathrm{~m}, 4 \mathrm{~F}),-123.2(\mathrm{~m}, 2 \mathrm{~F})$, -126.7 (m, 2F); MS (70 eV): 488 (100) $\mathrm{M}^{+}$, 469 (47) $[\mathrm{M}-\mathrm{F}]^{+}, 419$ (2) $\left[\mathrm{M}-\mathrm{CF}_{3}\right]^{+}$; IR: $2124 \mathrm{~cm}^{-1}(\mathrm{C} \equiv \mathrm{C}), 3320(\equiv \mathrm{C}-\mathrm{H})$.

\section{Polymerization and Film Preparation}

In a flask were placed tungsten hexachloride, tetraphenyltin as cocatalyst, and toluene. The solution was aged with stirring at $40^{\circ} \mathrm{C}$ for $30 \mathrm{~min}$. After the addition of a monomer to this catalyst solution, polymerization was carried out at $40^{\circ} \mathrm{C}$ for $24 \mathrm{~h}$. The polymer was purified by pouring the mixture into methanol followed by reprecipitation.

Polymer films were prepared by casting $c a$. $5 \mathrm{wt} \% p$-bis(trifluoromethyl)benzene solutions of the polymers on a glass surface and allowing the solvent to evaporate at room temperature. The films were stripped from the glass surface by immersion in water and dried under vacuum at $40^{\circ} \mathrm{C}$ for $24 \mathrm{~h}$. Membrane thickness ranged from 40 to $90 \mu \mathrm{m}$.

\section{Permeability Measurement}

The gas permeability of polymer films was estimated at $25^{\circ} \mathrm{C}$ by gas chromatography using air, where a membrane on a porous support was fixed horizontally in a holder. The upstream side of the membrane was maintained at the atmospheric pressure and the downstream side at $c a .10^{-2} \mathrm{mmHg}$.

In pervaporation, a $10 \mathrm{wt} \%$ aqueous solution of organic liquid was fed to the upside of a membrane and the downstream side was maintained at ca. $10^{-1} \mathrm{mmHg}$. Under this condition, the membrane was allowed to stand overnight and permeates were sampled after a steady state had been reached.

The composition and flux of permeate were estimated at $25^{\circ} \mathrm{C}$ by a gas chromatograph connected directly to the pervaporation cell. The permeation rate, $P$ in $\mathrm{g} \cdot \mathrm{m} \cdot \mathrm{m}^{-2} \cdot \mathrm{h}^{-1}$, was calculated by correcting flux for membrane thickness. The separation factor, $\alpha$, a measure of the preferential permeation of component $\mathrm{A}$, was defined as the concentra- tion ratio $Y_{\mathrm{A}} / Y_{\mathrm{B}}$ in the permeate divided by the concentration ratio $X_{\mathrm{A}} / X_{\mathrm{B}}$ in the feed, where $\mathrm{A}$ and $\mathrm{B}$ indicate an organic liquid and water, respectively.

\section{Instruments}

IR spectra were taken with a JASCO IR810 infrared spectrophotometer. Mass spectra were obtained with a Shimadzu GCMS-7000 $(70 \mathrm{eV}) .{ }^{1} \mathrm{H}$ NMR $(90 \mathrm{MHz})$ and ${ }^{19} \mathrm{~F}$ NMR $(84.67 \mathrm{MHz})$ measurements were recorded on a Hitachi R-90H instrument. Chemical shifts were defined as $\delta$ values relative to TMS and $\mathrm{CFCl}_{3}$, respectively. Molecular weights of polymers were determined by a HewlettPackard 502 high speed membrane osmometer using $p$-bis(trifluoromethyl)benzene as a solvent. Thermogravimetry was performed with a Seiko I \& E TG-20 at a heating rate of $10^{\circ} \mathrm{C} \mathrm{min}^{-1}$. Gas permeability coefficients of the films were measured with a Yanako GTR-10 and pervaporations were performed with a Yanako GTR-12L.

\section{RESULTS AND DISCUSSION}

Perfluoroalkylated phenylacetylene monomers were synthesized according to Scheme 1 . The reactions of disubstituted benzenes with 1,1-dichloro-2,2-difluoroethylene following lithiation afforded compounds substituted by the vinyl groups preferentially at ortho-positions on the trifluoromethyl groups, though traces of other isomers were detected by ${ }^{19} \mathrm{~F}$ NMR for $\mathbf{2 a}$ and $\mathbf{2 c}$.

The polymers were obtained by using a tungsten hexachloride-tetraphenyltin catalyst system (Table I). The reddish brown solids formed exhibited no decrease in weight up to $290^{\circ} \mathrm{C}$. A distinct glass transition of the polymers could not be observed by differential scanning calorimetry over the range below the decomposition temperature. Poly(3a) and poly $(3 \mathbf{c})$ were completely soluble in $p$-bis(trifluoromethyl)benzene, but insoluble in toluene, chloroform, acetone, and fluorinated solvents 


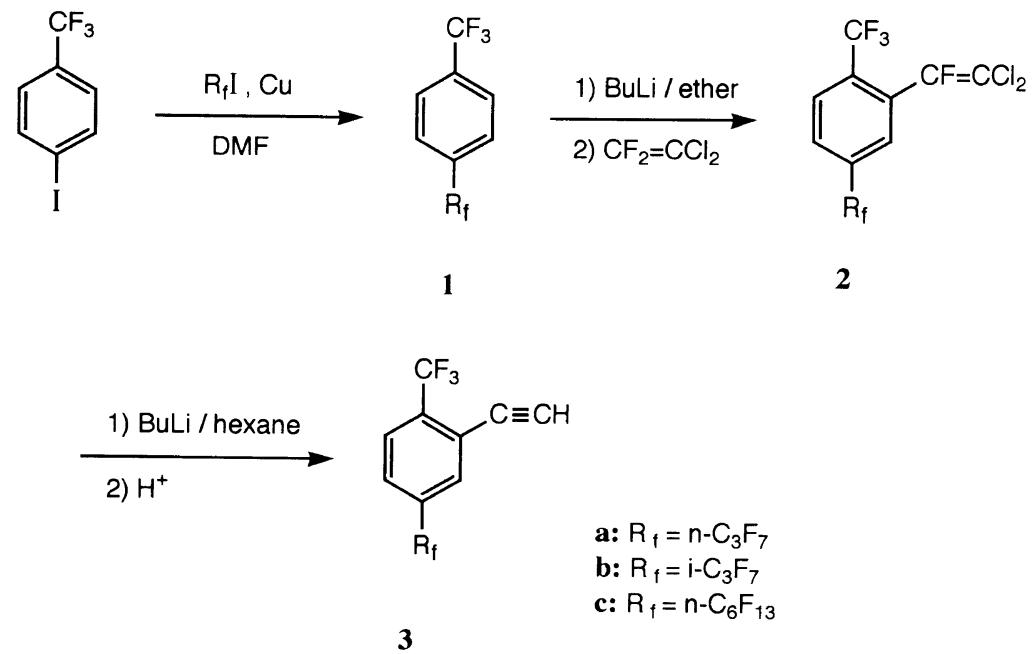

Scheme 1.

Table I. Polymerization of perfluoroalkylated phenylacetylenes $^{\mathrm{a}}$

\begin{tabular}{cccc}
\hline \multirow{2}{*}{ Monomer } & Yield & & $\overline{M_{n}}{ }^{\mathrm{b}}$ \\
\cline { 2 - 2 } & $\%$ & & $\left(10^{5}\right)$ \\
\hline 3a & 87 & & 4.5 \\
3b & 31 & & $\overline{6}^{\mathrm{c}}$ \\
\hline
\end{tabular}

${ }^{\mathrm{a}}[$ Monomer $]=1.0 \mathrm{~mol} \mathrm{l}^{-1},\left[\mathrm{WCl}_{6}\right]=\left[\mathrm{Ph}_{4} \mathrm{Sn}\right]=0.010$ mol 1-1.

b Determined by a membrane osmometer in $p$-bis(trifluoromethyl)benzene.

c Insoluble.

such as hexafluorobenzene, 1,1,2-trichlorotrifluoroethane, and $m$-bis(trifluoromethyl)benzene. In contrast, poly(3b) was insoluble even in $p$-bis(trifluoromethyl)benzene. Poly(3a) and poly(3c), which were soluble and had molecular weight over $10^{5}$, gave tough films by the solution casting technique.

Gas permeability of the films was estimated for $\mathrm{O}_{2}$ and $\mathrm{N}_{2}$, and the results are compared with those for poly[(2-trifluoromethylphenyl)acetylene] (TFPA) and poly[[2,5-bis(trifluoromethyl)phenyl]acetylene] (BTPA) (Table II). ${ }^{3}$ Poly(3a) and poly(3c) showed higher oxygen permeability coefficients than TFPA,
Table II. Gas permeability of poly $\left(2-\mathrm{CF}_{3}-5-R_{\mathrm{f}}\right.$-phenylacetylene $) \mathrm{s}^{\mathrm{a}}$

\begin{tabular}{ccclc}
\hline Polymer & \multicolumn{1}{c}{$R_{\mathrm{f}}$} & $P_{\mathrm{O}_{2}}{ }^{\mathrm{b}}$ & $P_{\mathrm{N}_{2}}{ }^{\mathrm{b}}$ & $P_{\mathrm{O}_{2}} / P_{\mathrm{N}_{2}}$ \\
\hline Poly(3a) & $n-\mathrm{C}_{3} \mathrm{~F}_{7}$ & 3.1 & 1.4 & 2.2 \\
Poly(3c) & $n-\mathrm{C}_{6} \mathrm{~F}_{13}$ & 1.1 & 0.46 & 2.4 \\
\hline TFPA & $\mathrm{H}$ & 0.32 & 0.076 & 4.2 \\
BTPA & $\mathrm{CF}_{3}$ & 4.5 & 2.0 & 2.3 \\
\hline
\end{tabular}

a Measured at $25^{\circ} \mathrm{C}$.

b In $10^{-8} \mathrm{~cm}^{3}(\mathrm{STP}) \mathrm{cm} \cdot \mathrm{cm}^{-2} \mathrm{~s}^{-1} \mathrm{cmHg}^{-1}$.

but lower than BTPA. The gas permeability of the polymers tended to increase by the introduction of perfluoroalkyl groups into the benzene rings, but decreased as the perfluoroalkyl group became longer. Poly(phenylacetylene)s had high gas permeability on increasing the number of trifluoromethyl groups per monomer unit. ${ }^{3}$ Thus bulkyl but short side chains appear to improve the gas permeability effectively in this series of polymers. In a polymer with long perfluoroalkyl side chains, an aggregation of brances may reduce the gas permeability of the membrane. ${ }^{9}$

Table III summarizes the results of pervaporation measurements of $10 \%$ aqueous ethanol solution through the membranes of 
Table III. Permeation rate and separation factor in pervaporation of $10 \%$ aqueous solution of ethanol ${ }^{\mathrm{a}}$

\begin{tabular}{lccl}
\hline Polymer & $R_{\mathrm{f}}$ & $P^{\mathrm{b}}$ & $\alpha^{\mathrm{EtOH}}$ \\
\hline TFPA & $\mathrm{H}$ & 1.8 & 0.15 \\
BTPA & $\mathrm{CF}_{3}$ & 10 & 0.93 \\
Poly(3a) & $n-\mathrm{C}_{3} \mathrm{~F}_{7}$ & 0.76 & 1.1 \\
Poly(3c) & $n-\mathrm{C}_{6} \mathrm{~F}_{13}$ & 0.81 & 1.3 \\
\hline
\end{tabular}

a Measured at $25^{\circ} \mathrm{C}$.

b In $10^{-4} \mathrm{~g} \cdot \mathrm{m} \cdot \mathrm{m}^{-2} \mathrm{~h}^{-1}$.

Table IV. Pervaporation of $10 \%$ aqueous solution of organic liquids through poly $(3 c)^{a}$

\begin{tabular}{ccc}
\hline \multicolumn{1}{c}{ Feed } & $P^{\mathrm{b}}$ & $\alpha^{\text {Org. }}$ \\
\hline Acetone $/ \mathrm{H}_{2} \mathrm{O}$ & 2.8 & 24 \\
$\mathrm{THF} / \mathrm{H}_{2} \mathrm{O}$ & 2.3 & 5.1 \\
\hline
\end{tabular}

a Measured at $25^{\circ} \mathrm{C}$.

b In $10^{-4} \mathrm{~g} \cdot \mathrm{m} \cdot \mathrm{m}^{-2} \mathrm{~h}^{-1}$.

perfluoroalkyl-substituted poly(phenylacetylene)s. BTPA had the largest permeation rate in this series of polymers. Although permeation rates and separation factors are relatively low, ethanol permeated preferentially through poly(3a) and poly(3c). The separation factors of ethanol to water slightly increased with length of the perfluoroalkyl groups.

Pervaporation is controlled by the mass transport mechanism described in the solution-diffusion model. ${ }^{10}$ Diffusivity of penetrating molecules in a polymer matrix is thought to depend on molecular dimensions in case no special interaction exists. ${ }^{11}$ Thus the pref- erential permeation of ethanol, which has the disadvantage in diffusion, is attributable to the higher solubility of ethanol in the polymer films. Pervaporations of aqueous acetone and tetrahydrofuran through poly $(3 \mathbf{c})$ were also performed, and the results are shown in Table IV. The organic components permeated preferentially in both cases with larger permeation rates and separation factors than those in aqueous ethanol solution. This would arise from the remarkable hydrophobicity of the polymers, which is favorable for dissolution of the organic components into the films.

\section{REFERENCES}

1. M. Langsam, M. Anand, and E. J. Karwacki, Gas Separation \& Purification, 2, 162 (1988).

2. M. R. Coleman and W. J. Koros, J. Membrane Sci., 50, 285 (1990).

3. Y. Hayakawa, M. Nishida, T. Aoki, and H. Muramatsu, J. Polym. Sci., Polym. Chem. Ed., 30, 873 (1992).

4. T. Masuda and T. Higashimura, Adv. Polym. Sci., 81, 121 (1986).

5. J. Kunzler and V. Percec, J. Polym. Sci., Polym. Chem. Ed., 28, 1221 (1990).

6. T. Masuda, T. Hamano, T. Higashimura, T. Ueda, and H. Muramatsu, Macromolecules, 21, 281 (1988).

7. K. Okuhara, J. Org. Chem., 41, 1487 (1976).

8. V. C. R. McLoughlin and J. Thrower, Tetrahedron, 25, 5921 (1969).

9. V. V. Volkov, N. A. Platé, A. Takahara, T. Kajiyama, N. Amaya, and Y. Murata, Polymer, 33, 1316 (1992).

10. C. H. Lee, J. Appl. Polym. Sci., 19, 83 (1975).

11. C. M. Bell, F. J. Gerner, and H. Strathmann, J. Membrane Sci., 36, 315 (1988). 